\title{
Mechanisms Generating Dual-Component Nicotinic EPSCs in Cortical Interneurons
}

\author{
Corbett Bennett, ${ }^{1 \star}$ Sergio Arroyo, ${ }^{1 \star}$ Dominic Berns, $^{2}$ and Shaul Hestrin ${ }^{1}$ \\ ${ }^{1}$ Department of Comparative Medicine, Stanford University School of Medicine, and ${ }^{2}$ Department of Biology, Stanford University, Stanford, California \\ 94305
}

Activation of cortical nicotinic receptors by cholinergic axons from the basal forebrain (BF) significantly impacts cortical function, and the loss of nicotinic receptors is a hallmark of aging and neurodegenerative disease. We have previously shown that stimulation of $\mathrm{BF}$ axons generates a fast $\alpha 7$ and a slow non- $\alpha 7$ receptor-dependent response in cortical interneurons. However, the synaptic mechanisms that underlie this dual-component nicotinic response remain unclear. Here, we report that fast $\alpha 7$ receptormediated EPSCs in the mouse cortex are highly variable and insensitive to perturbations of acetylcholinesterase (AChE), while slow non- $\alpha 7$ receptor-mediated EPSCs are reliable and highly sensitive to AChE activity. Based on these data, we propose that the fast and slow nicotinic responses reflect differences in synaptic structure between cholinergic varicosities activating $\alpha 7$ and non- $\alpha 7$ classes of nicotinic receptors.

\section{Introduction}

Cholinergic axons from the basal forebrain (BF) activate nicotinic acetylcholine receptors (nAChRs) throughout the cortex and play an important role in sensory processing (Metherate and Hsieh, 2004; Disney et al., 2007), attention (Howe et al., 2010), and learning (Gu and Yakel, 2011; Letzkus et al., 2011; for review see Levin, 2002). Moreover, loss of cholinergic function is associated with several neurodegenerative diseases including Alzheimer's disease, for which cholinergic cell death and the loss of nAChRs in cortex are hallmarks of disease progression (Martin-Ruiz et al., 1999).

Despite its functional importance, the synaptic properties of nicotinic receptor-mediated signaling in the cortex remain poorly understood. Anatomical studies have shown that a fraction of cholinergic varicosities in the cortex form synaptic structures, while others are not associated with any postsynaptic membrane (Mrzljak et al., 1993; Umbriaco et al., 1994; Turrini et al., 2001). Although the precise ratio of synaptic to nonsynaptic cholinergic varicosities has been disputed, recent findings suggest that the cholinergic system may operate primarily by volume transmission (Yamasaki et al., 2010; for review, see Lendvai and Vizi, 2008).

In the cortex, nAChRs are classified into two families: homomeric receptors composed of the $\alpha 7$ subunit and heteromeric

Received July 24, 2012; revised Sept. 11, 2012; accepted Sept. 18, 2012.

Author contributions: C.B., S.A., and S.H. designed research; C.B., S.A., and D.B. performed research; C.B. and S.A. analyzed data; C.B., S.A., and S.H. wrote the paper.

This work was supported by NIH Grant EY012114, the Weston Havens Foundation, the Stanford Graduate Fellowship, the National Science Foundation Graduate Research Fellowship Program, the Stanford Medical Scientist Training Program, and the Ruth L. Kirschstein Graduate Fellowship. We thank Tony Ricci for contributing equipment used in the rapid application experiments.

${ }^{*}$ C.B. and S.A. contributed equally to this manuscript.

The authors declare no competing financial interests.

Correspondence should be addressed to Shaul Hestrin, 300 Pasteur Drive, Edwards R314, Department of Comparative Medicine, Stanford University School of Medicine.Stanford, CA 94305. E-mail: shaul.hestrin@stanford.edu. DOI:10.1523/JNEUROSCI.3565-12.2012

Copyright $\odot 2012$ the authors $\quad 0270-6474 / 12 / 3217287-10 \$ 15.00 / 0$ receptors composed of the $\beta 2$ subunit together with either the $\alpha 4$ or $\alpha 5$ subunit (Cordero-Erausquin et al., 2000). Homomeric nAChRs exhibit high calcium permeability, low ACh sensitivity, and rapid desensitization; whereas heteromeric receptors exhibit low calcium permeability, high ACh affinity, and relatively slow kinetics (Dani and Bertrand, 2007). These diverse properties may allow homomeric $\alpha 7$ and heteromeric non- $\alpha 7$ nicotinic receptors to respond to distinct spatiotemporal ACh profiles produced by activation of synaptic and nonsynaptic cholinergic varicosities. However, without a method allowing selective stimulation of cholinergic axons, the roles of specific nicotinic receptor subtypes in cholinergic signaling remain unclear.

We recently found that stimulation of BF cholinergic axons produces dual-component responses consisting of a fast $\alpha 7$ receptor-mediated response and a slow non- $\alpha 7$ receptor-mediated response (Arroyo et al., 2012). These findings gave rise to the hypothesis that the fast component is mediated by conventional synaptic contacts whereas the slow response is mediated by transmitter diffusing over some distance (i.e., volume transmission). Here we investigated mechanisms that may underlie the dualcomponent nicotinic response in cortical interneurons.

\section{Materials and Methods}

Animals. Both a BAC transgenic (GENSAT GM24; Tamamaki et al., 2003) and a knock-in mouse line (Rossi et al., 2011) expressing Cre recombinase (Cre) under the choline acetyltransferase promoter were used to transduce cholinergic neurons in the BF with a channelrhodopsin-2-enhanced yellow fluorescent protein (ChR2-EYFP) construct. The expression of Cre in the BF was similar for both ChAT-Cre mouse lines, and subsequent data were pooled. All procedures were approved by the Administrative Panel on Laboratory Animal Care at Stanford University.

Viral transduction of the basal forebrain. Both male and female mice aged P20-P60 were anesthetized and placed in a stereotaxic frame. AAV2/5 virus $(1-2 \mu \mathrm{l})$ bearing a pAAV-EF1 $\alpha$-DIO-hChR2 (H134R)EYFP-WPRE (Zhang et al., 2010) construct were pressure injected into 
A

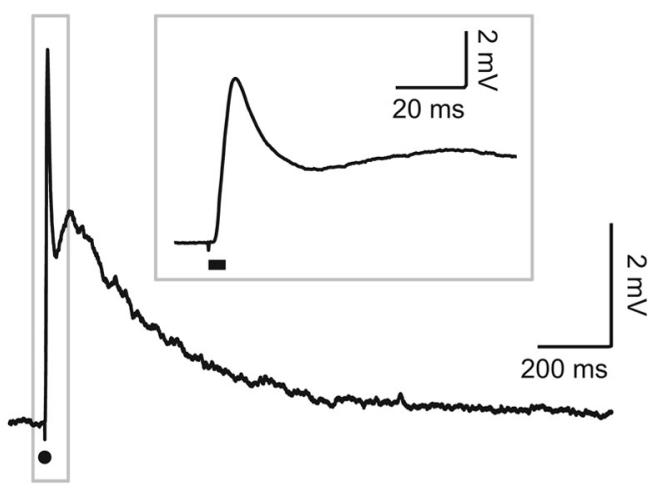

B

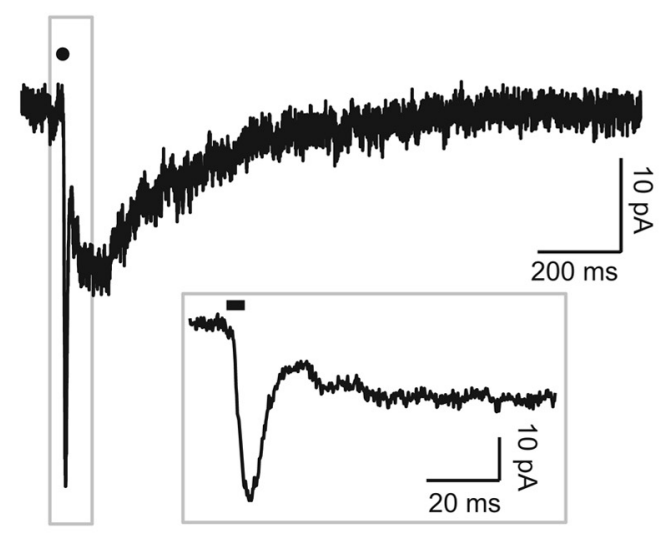

C

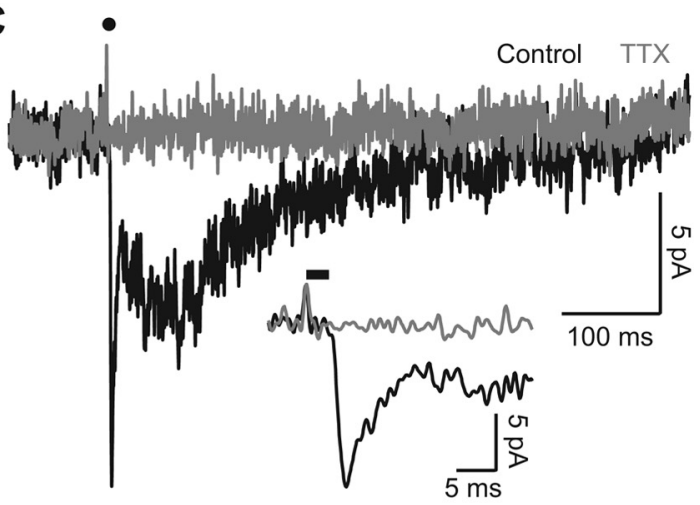

D

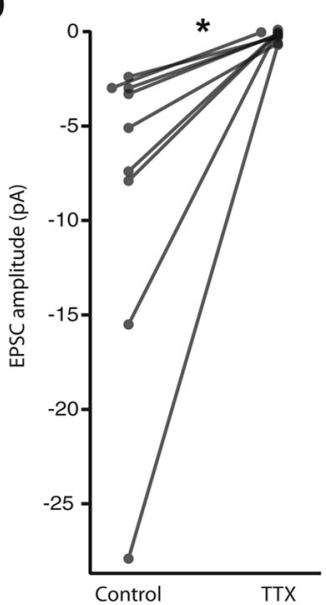

Fast EPSC

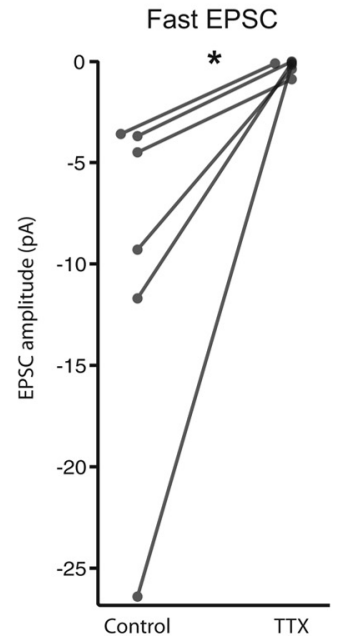

Figure 1. Dual-component nicotinic EPSCS in L1 interneurons. $A$, Dual-component synaptic response of an L1 interneuron to photostimulation of cholinergic fibers recorded under current clamp. Inset, Fast component depicted on expanded timescale. This cell was not included in Arroyo et al., 2012. B, Synaptic response recorded from the same neuron as in $\boldsymbol{A}$ under voltage clamp. Inset, Expanded timescale. C, Dual-component response in an L1 interneuron before (black) and after (gray) application of TTX (0.5 $\mu \mathrm{M})$. Inset, Fast component depicted on expanded timescale. $\boldsymbol{D}$, Amplitude of the slow (left; $n=9$ ) and fast (right; $n=6$ ) EPSCs before and after application of $\operatorname{TTX}^{*} p<0.05$, Wilcoxon signed-rank test. Overlapping data points were horizontally offset for clarity. $A-D$, Black circles and tick marks represent photostimulation.

the brain using stereotaxic coordinates for several basal forebrain nuclei, including the nucleus basalis, the horizontal diagonal band of Broca, and the substantia innominata. Typically, four sites were injected, with no more than $500 \mathrm{nl}$ of virus in each location.

Slice preparation. Six to 20 weeks after surgery, mice were deeply anesthetized with isoflurane. Brains were removed in ice-cold, carbogenated sucrose composed of the following (in $\mathrm{mm}$ ): $76 \mathrm{NaCl}, 25$ NaHCO3, 25 glucose, 75 sucrose, $2.5 \mathrm{KCl}, 1.75 \mathrm{NaHPO}_{4}, 0.5 \mathrm{CaCl} 2,7$ $\mathrm{MgSO}_{4} 2$ pyruvic acid, 4 lactic acid, $4 \beta$-hydroxybutyric acid. Sagittal slices (300- $\mu \mathrm{m}$-thick) were generated (Integraslice $7550 \mathrm{MM}$; Campden Instruments) and transferred to a chamber with the same solution maintained at $32-35^{\circ} \mathrm{C}$. After $30 \mathrm{~min}$, the slices were transferred to artificial CSF (ACSF) composed of the following (in $\mathrm{mM}$ ): 125 $\mathrm{NaCl}, 2.5 \mathrm{KCl}, 1.25 \mathrm{NaH}_{2} \mathrm{PO}_{4}, 1 \mathrm{MgSO}_{4} 2 \mathrm{CaCl} 2,26 \mathrm{NaHCO} 3,20$ glucose, 4 lactic acid, 2 pyruvic acid, 0.4 ascorbic acid, and 4 $\beta$-hydroxybutyric acid at $32-35^{\circ} \mathrm{C}$. Slices were allowed to equilibrate to room temperature before being transferred to the microscope chamber.

Electrophysiological recordings. Glass electrodes (3-7 M $\Omega$ ) were filled with an internal solution composed of the following (in mM)2.7 $\mathrm{KCl}, 120$ potassium methyl sulfate, 9 HEPES, 0.18 EGTA, 4 MgATP, $0.3 \mathrm{NaGTP}, 20$ sodium phosphocreatine, $\mathrm{pH}$ 7.3, $295 \mathrm{mOsm} / \mathrm{L}$. To test for the contribution of electrical coupling to the slow response, the above solution was modified by replacing $\mathrm{KCl}$ with $\mathrm{CsCl}(3.3 \mathrm{~mm})$ and potassium methyl sulfate with cesium methanesulfonate (133 $\mathrm{mm}$ ). Whole-cell patch-clamp recordings were obtained by using two Axopatch $200 \mathrm{~B}$ or $700 \mathrm{~A}$ patch amplifiers (Molecular Devices) in current-clamp or voltage-clamp modes. Data acquisition and offline analysis were performed using custom software written in IGOR Pro (Wavemetrics). For photostimulation, blue light was emitted either from an LED attached to a fiber optic cable $(920-\mu$ m-diameter $)$ or a xenon lamp with a mechanical shutter (Uniblitz). The spot used to illuminate the slice ranged from 200 to $450 \mu \mathrm{m}$ in diameter and the light intensity ranged from 10 to $400 \mathrm{~mW} / \mathrm{mm}^{2}$. Photostimulations were typically $3-10 \mathrm{~ms}$ long, and $2-5 \mathrm{~min}$ were allowed between stimulations, except for paired pulse experiments for which the interstimulus interval was varied systematically from $0.5-16 \mathrm{~s}$. For pharmacological experiments, TTX, DNQX, methyllycaconitine (MLA), and dihydro- $\beta$-erythroidine (DH $\beta \mathrm{E} ;)$, and ambenonium dichloride were diluted in ACSF to $0.5 \mu \mathrm{M}, 10 \mu \mathrm{M}, 5 \mathrm{nM}, 500 \mathrm{~nm}$, and $100 \mathrm{nM}$, respectively, and bath applied. For the acetylcholinesterase (AChE) experiment, AChE (0.4 U/ $\mu$ l; Sigma-Aldrich C2888) was pressure ejected continuously from a patch pipette at low pressure $(\sim 2 \mathrm{psi})$.

Nucleated patches and rapid perfusion. Nucleated patches were pulled as described previously (Ford et al., 2009). Briefly, after obtaining wholecell recordings, gentle suction was applied while slowly retracting the pipette to extract the nucleus from the cell. The nucleated patch was then positioned beside the agonist stream flowing from an application pipette, $\sim 500 \mu \mathrm{m}$ above the slice surface. The application pipette was attached to a commercial piezoelectric device (Burleigh PZ-150M) or a bimorph strip. A brief voltage step was applied to induce a small deflection of the application pipette, moving the agonist stream over the nucleated patch. The voltage step applied to both actuators was low-pass filtered at $100 \mathrm{~Hz}$ to reduce oscillations. 
Analysis. To quantify the effect of ambenonium dichloride on the time course of nicotinic EPSCs, the interval between the peak current and subsequent half-maximum amplitude $\left(t_{\text {half } \max }\right)$ was calculated as follows. Traces were filtered at $1 \mathrm{kHz}$, and the response decay was fit by a double exponential function, $f(t)$. $t_{\text {half } \max }$ was defined as the time interval from the peak to $t_{1 / 2}$, where $t_{1 / 2}$ was the time at which $f(t)=(1 / 2) \times$ (peak - baseline) + baseline.

To calculate the coefficient of variation, the amplitudes of the fast and slow components were found independently. For the fast component, a 2 $\mathrm{ms}$ window was averaged around the minimum between 0 and $20 \mathrm{~ms}$ after photostimulation. For the slow component, $20 \mathrm{~ms}$ was averaged around the minimum between 20 and $1000 \mathrm{~ms}$ after photostimulation. The amplitudes of both components were detrended before variance analysis. Two noise amplitudes, one generated using the parameters for the fast component and one for the slow component, were obtained over baseline intervals and noise variances were calculated. These were subtracted from the respective response variances to correct for noise variance. All values are reported as mean $\pm \mathrm{SE}$ unless otherwise indicated. The nonparametric Wilcoxon signed-rank test was used for all paired statistical comparisons. The Wilcoxon rank-sum test was used for all nonpaired statistical comparisons.

\section{Results \\ Perturbations of AChE activity exclusively impact the non- $\alpha 7$ response}

To study the mechanisms underlying dual-component nicotinic responses in the cortex, we recorded from $\mathrm{L} 1$ interneurons while photostimulating ChR2-expressing cholinergic BF axons (see Materials and Methods, above). We recently demonstrated that this interneuron subtype exhibits dual-component nicotinic responses to photostimulation (Arroyo et al., 2012), an example of which is shown in Figure 1, $A$ and $B$. These EPSCs were abolished by application of the sodium channel blocker TTX $(0.5 \mu \mathrm{M})$, indicating that both the fast and slow components were dependent on action potentials in cholinergic axons (slow EPSC control amplitude: $-8.4 \pm 2.8 \mathrm{pA}$; slow EPSC TTX amplitude: $-0.2 \pm 0.1 \mathrm{pA} ; n=9, p<0.01$, Wilcoxon signed-rank test; fast EPSC control amplitude: $-9.9 \pm 3.6 \mathrm{pA}$; fast EPSC TTX amplitude: $-0.3 \pm 0.1 \mathrm{pA} ; n=6, p<0.05$, Wilcoxon signed-rank test; Fig. $1 C, D)$. The rise and decay of the slow nicotinic EPSC are $>10$-fold slower than the rise and decay of the fast EPSC (fast rise time: $2.6 \pm 0.5 \mathrm{~ms}$; fast decay $\tau: 4.9 \pm 0.6 \mathrm{~ms}$; slow rise time: $35 \pm$ $5 \mathrm{~ms}$; slow decay $\tau: 190 \pm 17 \mathrm{~ms}$ ) (Arroyo et al., 2012). We hypothesized that the difference in the kinetics of the $\alpha 7$ and non- $\alpha 7$ components results from different localization of these receptors with respect to $\mathrm{ACh}$ release sites; i.e., the slow kinetics of the non- $\alpha 7$ EPSC reflect diffusion of ACh from distant varicosities to activate nonsynaptic receptors, while the fast kinetics of the $\alpha 7$-mediated component reflect conventional synaptic transmission (Vizi, 2000).

If non- $\alpha 7$ receptors are indeed located farther from release sites, then the slow non- $\alpha 7$ receptor-mediated response should be more susceptible to hydrolysis of ACh by AChE. We found that application of the AChE inhibitor ambenonium dichloride (100 nM) (Hodge et al., 1992) dramatically prolonged the decay of the slow component (Fig. 2A). To determine the effect of AChE blockade on the fast component, we first bath applied the selective non- $\alpha 7$ receptor antagonist $\mathrm{DH} \beta \mathrm{E}(500 \mathrm{~nm})$ to block the slow non- $\alpha 7$ response. Subsequent addition of ambenonium had no effect on the kinetics of the fast response (Fig. 2B). To quantify the effect of AChE inhibition, we measured the interval between the peak of the nicotinic EPSC and the subsequent half-maximum, $t_{1 / 2}$, before and after the addition of ambenonium (slow control $t_{1 / 2}$ : $119 \pm 9 \mathrm{~ms} ; n=8$; slow ambenonium $t_{1 / 2}: 1050 \pm 250 \mathrm{~ms}$;
A Control Ambenonium

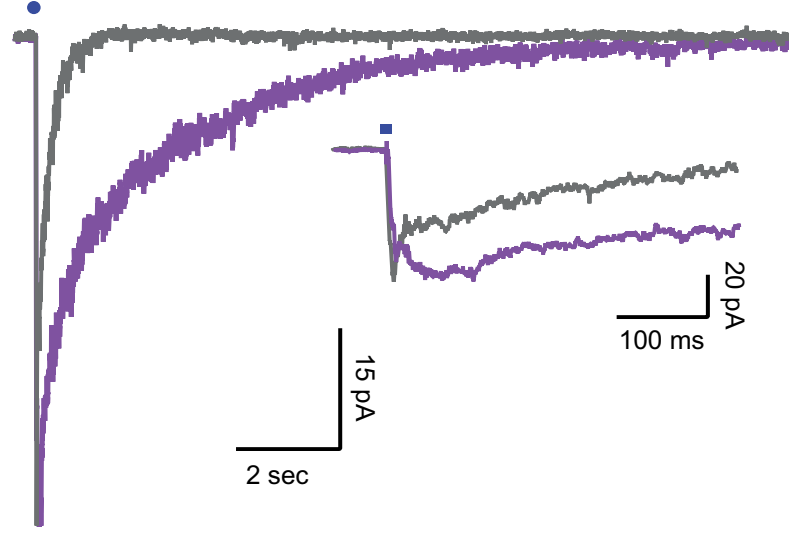

B
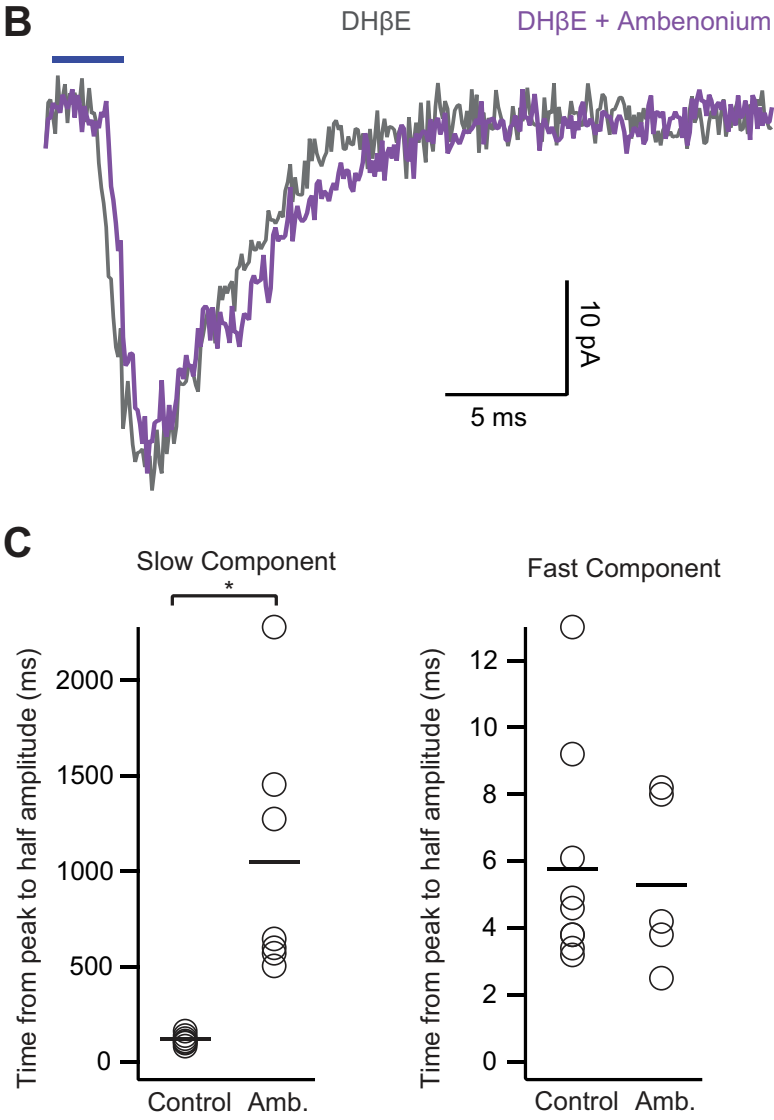

Figure 2. Fast and slow nicotinic EPSCs are differentially impacted by blockade of AChE. $A$, Dual-component nicotinic EPSC of an L1 interneuron before (gray) and after (purple) application of the AChE inhibitor ambenonium dichloride (100 nм). Inset, Expanded timescale. $\boldsymbol{B}$, Fast component of a $\mathrm{L} 1$ interneuron after selectively abolishing the slow component with $\mathrm{DH} \beta \mathrm{E}$ ( $500 \mathrm{~nm}$; gray) and subsequently applying ambenonium ( $100 \mathrm{~nm}$; purple). C, Left, Time from peak current to half amplitude for the slow EPSC recorded in control $\operatorname{ACSF}(n=8)$ and ambenonium (Amb.; $n=7)$. Right, Time from peak current to half amplitude for the fast EPSC recorded in control ACSF $(n=8)$ and ambenonium $(n=7)$. ${ }^{*} p<0.001$, Wilcoxon rank-sum test. $A-C$, Blue circles and tick marks represent photostimulation.

$n=7, p<0.001$, Wilcoxon rank-sum test; fast control $t_{1 / 2}$ : $5.8 \pm 1.1 \mathrm{~ms}, n=9$; fast ambenonium $t_{1 / 2}: 5.3 \pm 1.1 \mathrm{~ms} ; n=$ $5, p>0.05$, Wilcoxon rank-sum test; Fig. 2C). These data suggest that the time course of the slow component, but not the fast component, depends on the hydrolysis of ACh by AChE. 

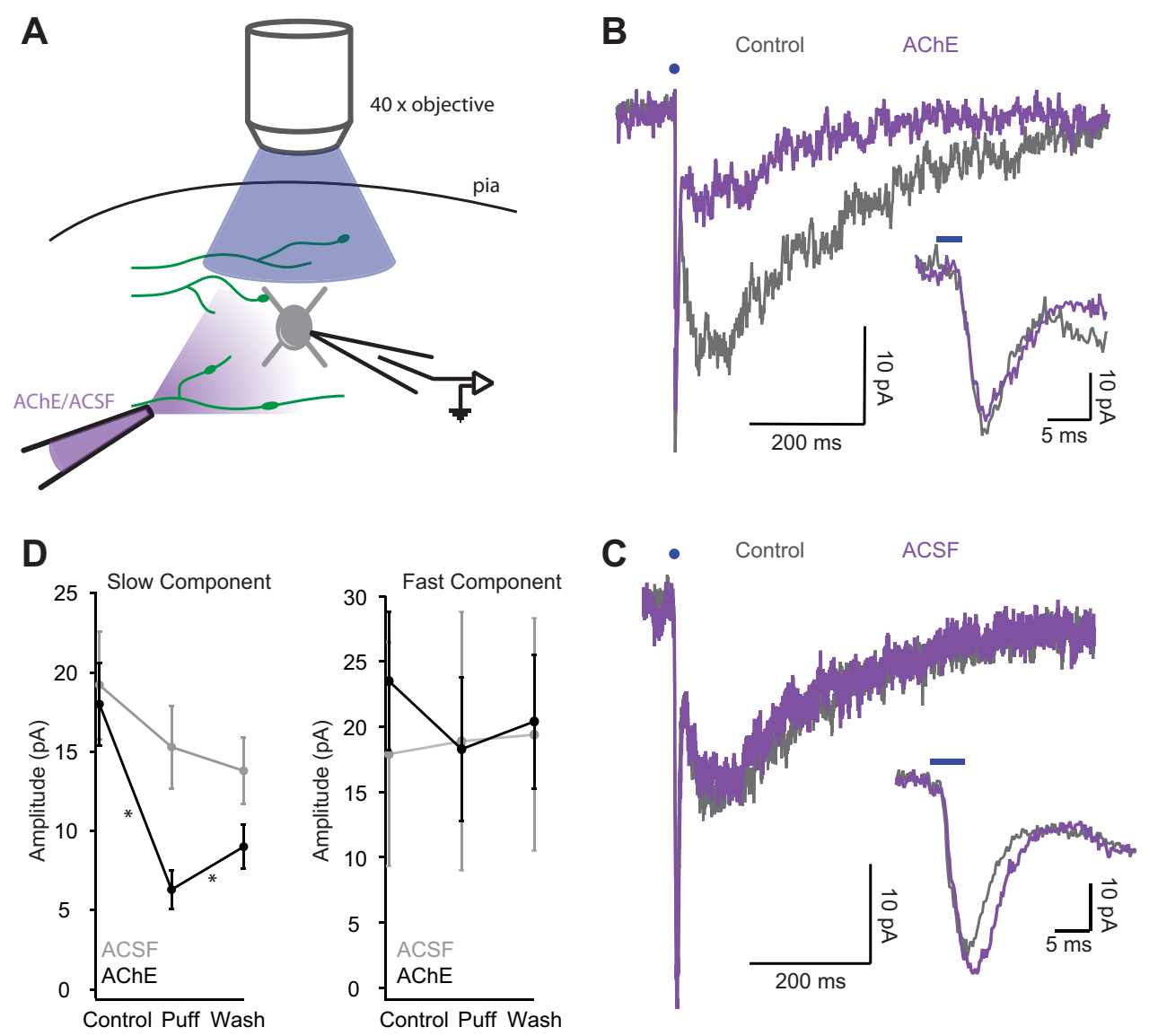

Figure 3. Fast and slow nicotinic EPSCS are differentially impacted by application of exogenous AChE. $A$, Schematic illustrating experimental setup. Whole-cell recordings were obtained from L1 cells while photostimulating cholinergic fibers and pressure ejecting AChE or ACSF via a second patch pipette. $\boldsymbol{B}$, Dual-component nicotinic response of an L1 interneuron before (gray) and after (purple) application of AChE $(0.4 \mathrm{U} / \mu \mathrm{l})$. Inset, Expanded timescale. C, Dual-component nicotinic response of an $\mathrm{L} 1$ interneuron before (gray) and after (purple) application of ACSF. Inset, Expanded timescale. $\boldsymbol{D}$, Amplitude of slow (left) and fast (right) components plotted for nine L1 interneurons under control, puff, and wash conditions. ${ }^{*} p<$ 0.01 , Wilcoxon rank-sum test. $\boldsymbol{A}-\boldsymbol{D}$, Blue circles and tick marks represent photostimulation.

If the slow component relies on the diffusion of ACh from distant varicosities, then enhancing AChE activity should diminish the slow response. To test this hypothesis, we obtained wholecell recordings from L1 interneurons and applied exogenous AChE via pressure injection from a nearby patch pipette (Fig. $3 A)$. AChE was ejected continuously at low pressure for the duration of drug application trials. As predicted, application of AChE significantly reduced the amplitude of the slow component (control: $18 \pm 2.6 \mathrm{pA}$; AChE application: $6.3 \pm 1.2 \mathrm{pA}$; wash: $9.0 \pm 1.4 \mathrm{pA} ; n=9, p<0.005$, Wilcoxon signed-rank test; Fig. $3 B, D)$ but did not significantly affect the amplitude of the fast component (control: $24 \pm 5.3 \mathrm{pA}$; AChE application: $18 \pm 5.5$ pA; wash: $20 \pm 5.1 \mathrm{pA} ; n=6, p>0.05$, Wilcoxon signed-rank test; Fig. $3 B$, inset, $D$ ). As a control experiment, we showed that pressure application of ACSF did not affect the slow component (control: $19 \pm 3.4 \mathrm{pA}$; ACSF application: $15 \pm 2.6 \mathrm{pA}$; wash: $14 \pm$ $2.1 \mathrm{pA} ; n=7, p>0.05$, Wilcoxon signed-rank test; Fig. $3 C, D)$ or the fast component (control: $18 \pm 8.6 \mathrm{pA}$; ACSF application: $19 \pm 9.9$ pA; wash: $19.4 \pm 8.9$ pA; $n=3$; Fig. $3 C$, inset, $D$ ).Together, these data indicate that the slow response, but not the fast response, is sensitive to perturbations of AChE activity.

\section{Concentration dependence of $\alpha 7$ receptor-mediated response kinetics}

The selective effect of perturbing AChE suggests that the slow component depends on transmitter diffusing over relatively long distances, whereas the fast component depends on a short diffusion pathway (Figs. 2, 3). However, since $\alpha 7$ receptors are known to desensitize rapidly (Quick and Lester, 2002), it is also possible that the fast component reflects desensitization of nonsynaptic $\alpha 7$ receptors activated by ACh released from distant varicosities. In this scenario, the ACh transient mediating the fast $\alpha 7$ response would be relatively slow. Moreover, due to dilution and hydrolysis of ACh by AChE, the concentration of transmitter would be many fold lower than the concentration at synaptic contacts (Eccles and Jaeger, 1958). Thus, this hypothesis predicts that prolonged activation of $\alpha 7$ receptors by low concentrations of ACh would mimic the fast component of the nicotinic response.

To test this possibility, we obtained nucleated patches from L1 interneurons and used a piezoelectric device to rapidly apply ACh (Fig. 4A). Patches were exposed to prolonged application of ACh, sufficient to completely desensitize receptors. Under these conditions, application of ACh produced an inward current that was abolished by MLA ( $5 \mathrm{~nm}$; Fig. $4 B$ ) and displayed inward rectification (Fig. $4 C$ ), consistent with properties of $\alpha 7$ receptors. We did not observe non- $\alpha 7$ responses in nucleated patches, indicating that these receptors either are washed out from the soma or are not natively present in somatic membrane (Buisson et al., 1996). Both the rise time and the decay time constant of the response to rapid application varied with agonist concentration $(20-80 \%$ rise time ranged 
A

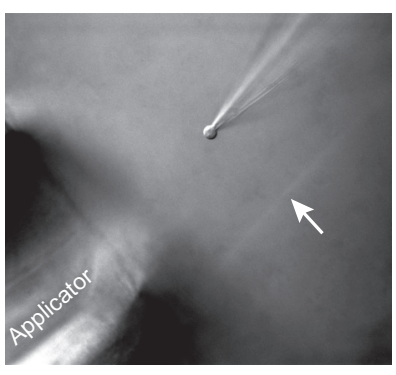

B

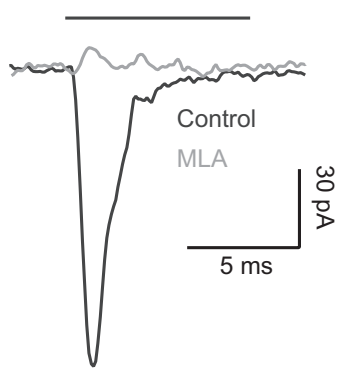

C

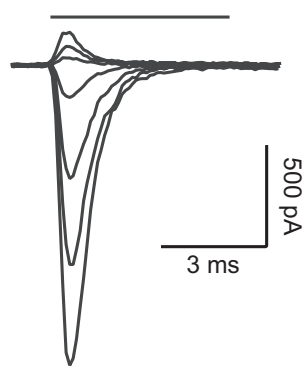

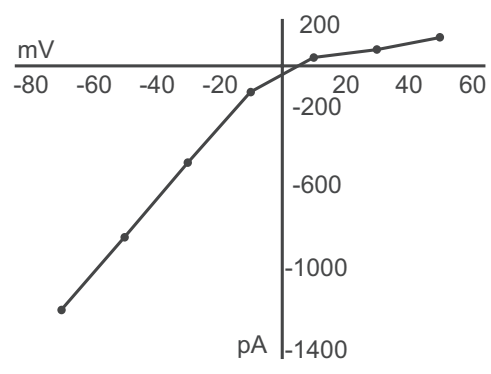

E

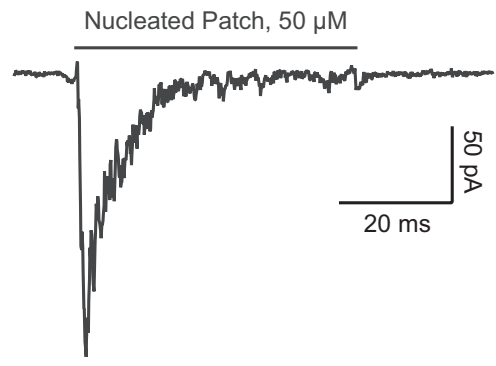

Synaptic Response in L1 interneuron

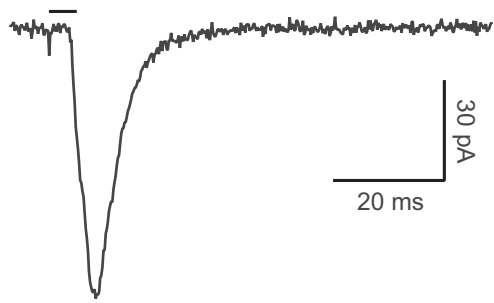

Figure 4. Concentration dependence of $\alpha 7$ receptor-mediated response kinetics. $A$, Differential interference contrast image depicting rapid application of ACh onto a nucleated patch from an L1 interneuron. Arrow indicates boundary of agonist stream. $B$, Response to an $8 \mathrm{~ms}$ application of ACh $(300 \mu \mathrm{M})$ in a nucleated patch from an L1 interneuron (black) is blocked by MLA ( $5 \mathrm{~nm}$; gray). C, Left, Nucleated patch responses to rapid application of ACh $(5 \mathrm{~ms})$ at eight holding potentials between -70 and $+50 \mathrm{mV}$. Right, I-V plot for same patch. D, Decay $\tau \mathrm{s}$ of responses to rapid application of ACh plotted as a function of concentration. Rapid application was performed on nucleated patches from L1 interneurons. Solid line represents a linear fit to the data plotted on a $\log -\log$ scale. Dotted lines indicate the range of decay $\tau \mathrm{s}$ from $\alpha 7$-mediated synaptic responses, plotted individually as open circles to the right. Error bars are 1SD. E, Top, Average response of a nucleated patch from an L1 interneuron to rapid application of $50 \mu \mathrm{m} \mathrm{ACh}$. Black bar, Duration of agonist application (50 ms). Bottom, Synaptic response in an $\mathrm{L} 1$ interneuron to photostimulation of cholinergic fibers demonstrating the time course of the fast component. Black bar represents photostimulation.

from $2.9 \pm 2.2 \mathrm{~ms}$ at $35 \mu \mathrm{M}$ ACh to $0.12 \pm 0.02 \mathrm{~ms}$ at $800 \mu \mathrm{M}$ ACh; $n=15$; decay time constant ranged from $36.2 \pm 6.3 \mathrm{~ms}$ at $20 \mu \mathrm{M}$ ACh to $0.5 \pm 0.1 \mathrm{~ms}$ at $800 \mu \mathrm{M}$ ACh; $n=19$; Fig. $4 D)$. From these data, we estimated the concentration of ACh that would evoke a nucleated patch response with the same decay kinetics as the $\alpha 7$-mediated EPSC (Fig. $4 E$ ). The average decay time constant of the synaptic $\alpha 7$ response was $4.9 \pm 0.6 \mathrm{~ms}$ with a range of 2.8-6.9 ms $(n=6$; Fig. $4 D)$. Thus, if the $\alpha 7$ EPSC is generated by a prolonged ACh transient, the concentration of transmitter required to produce the average synaptic response would be between 50 and $200 \mu \mathrm{M}$ (Fig. 4D). This estimate is more than tenfold greater than the concentration of ACh that has been proposed to mediate nonsynaptic transmission (Descarries et al., 1997). Moreover, since the decay time constants of somatically recorded EPSCs are likely overestimates of the unfiltered EPSC kinetics, the ACh concentration required to mimic synaptic responses probably exceeds our estimate. These data suggest that the kinetics of the fast component are unlikely to result from rapid desensitization of $\alpha 7$ receptors to a prolonged transient of dilute ACh. Thus, our results support the hypothesis that these receptors are located at synaptic contacts, where the peak concentration of transmitter has been estimated to range from 100 to $1000 \mu \mathrm{M}$ (Eccles and Jaeger, 1958; Clements, 1996).

\section{Paired-pulse depression is similar for fast and slow EPSCs}

To investigate whether the varicosities mediating the fast and slow components exhibit different release probabilities, we measured the recovery from paired-pulse depression [paired pulse ratio (PPR)] for the fast and slow EPSCs. We found that the two components recovered from paired-pulse depression at similar rates, as measured by single exponential fits to population PPR data $\left(\tau_{\text {fast PPR }}=2426 \pm 460 \mathrm{~ms} ; \tau_{\text {slow PPR }}=3260 \pm 606 \mathrm{~ms}\right.$; uncertainties represent 1 SD; Fig. $5 A$ ).

To ensure that this paired-pulse recovery did not simply reflect recovery from receptor desensitization, we compared the PPR time course for the fast synaptic EPSC with the recovery of $\alpha 7$ receptors from desensitization in nucleated patches (Fig. $5 B$ ). We found that $\alpha 7$ receptors recovered from desensitization on a much faster timescale than the synaptic paired-pulse recovery 
$\left(\tau_{\text {patch PPR }}=180 \pm 30 \mathrm{~ms}\right)$, indicating that receptor desensitization does not cause the paired-pulse depression observed in $\alpha 7$ receptor-mediated synaptic responses. Together, these data suggest that the fast and slow components are mediated by varicosities with similar release probabilities.

\section{Fast and slow nicotinic EPSCs exhibit different response variability}

The variability of synaptic responses depends on both the release probability of varicosities contributing to the postsynaptic response and the number of release sites. Given that the varicosities mediating the fast and slow components have similar release probabilities, nicotinic responses generated by few release sites should be more variable than responses mediated by many release sites (Del Castillo and Katz, 1954). Thus, if the non- $\alpha 7$ response reflects release from multiple nonsynaptic varicosities, but the $\alpha 7$ response reflects conventional synaptic transmission, then the slow component should exhibit lower variability than the fast component.

To study the response variability, we recorded from L1 interneurons under voltage clamp, allowing clear identification of the fast and slow components (Fig. $6 A$ ). To determine how the two components varied across the population of L1 interneurons, we plotted the amplitude of the slow EPSC against the amplitude of the fast EPSC for 39 cells (Fig. $6 A, B)$. We found no correlation between the fast and slow response amplitudes $(r=0.14$, linear correlation coefficient). Moreover, while several cells exhibited only a slow component $(n=14)$, we did not observe any responses consisting of only a fast component, suggesting that fewer ACh release sites contribute to the fast response.

To further examine response variability, we investigated how the two response components varied over multiple stimulations in single cells. Photostimulation of cholinergic fibers at $0.1-0.2$ $\mathrm{Hz}$ elicited responses in $\mathrm{L} 1$ interneurons that varied in amplitude from trial to trial (Fig. 6C). We found no correlation between the amplitude of the fast and slow components across multiple stimulations $(r=0.15 \pm 0.03$, average linear correlation coefficient for 6 cells). The fast component exhibited greater response variability, reflected by a significantly larger coefficient of variation $(\mathrm{CV})\left(\mathrm{CV}_{\text {fast }}: 0.49 \pm 0.08\right.$; $\mathrm{CV}_{\text {slow }}: 0.18 \pm 0.04 ; n=6, p<0.01$, Wilcoxon rank-sum test; Fig. $6 D$ ). Although we did not observe failures in the slow response, in several cells the fast component failed in a fraction of the trials (Fig. 6E).

Could the low variability of the slow response be explained by electrical coupling among L1 interneurons? Since these cells are known to be interconnected by gap junctions (Chu et al., 2003), the reliability of the slow component could reflect input onto many electrically coupled cells (d'Incamps et al., 2012). To test this possibility, we recorded nicotinic EPSCs while voltage clamping the postsynaptic neuron at -70 and 0 $\mathrm{mV}$ (see Materials and Methods, above). If the slow response is primarily mediated by current through gap junctions, then the response amplitude should be invariant to the holding poten- tial (d'Incamps et al., 2012). However, in every cell tested, we found that the slow EPSC was dramatically diminished at 0 $\mathrm{mV}$ (amplitude $_{0 \mathrm{mV}}$ /amplitude $-70 \mathrm{mV}: 0.13 \pm 0.02 ; n=3$; data not shown), suggesting that the majority of the response was mediated directly by nicotinic receptors on the recorded cell.

Selectively averaging trials in which the fast component failed or did not fail produced identical slow responses (amplitude slow: $_{\text {: }}$ : $13.2 \pm 9.0 \mathrm{pA}$; amplitude $_{\text {fast }}+$ slow $: 13.5 \pm 8.1 \mathrm{pA}$; decay $\tau_{\text {slow }}$ : $218 \pm 21 \mathrm{~ms}$; decay $\tau_{\text {fast }}+$ slow: $212 \pm 18 \mathrm{~ms} ; n=3$ cells; Fig. $6 F$ ), indicating negligible overlap between the varicosities mediating the two components. Since the release probability is similar across all varicosities (Fig. 5), these data suggest that more release sites contribute to the slow component than the fast component.

\section{Discussion}

We have investigated the mechanisms that underlie dualcomponent nicotinic signaling in L1 cortical interneurons. Previously, we have shown that excitation of cholinergic basal forebrain axons produces a fast $\alpha 7$ receptor-dependent response and a slow non- $\alpha 7$ receptor-dependent response (Arroyo et al., 2012). We propose that the fast $\alpha 7$ receptor-dependent response is mediated by conventional synaptic contacts whereas the slow non- $\alpha 7$ receptor-dependent response is mediated by nonsynaptic varicosities (Fig. 7).

\section{Mechanisms underlying the fast component}

Several lines of evidence suggest that the fast $\alpha 7$ receptordependent component is mediated by a conventional synapse. First, we found that inhibition of AChE, which dramatically prolonged the waveform of the slow component $(\sim 10$-fold), did not affect the fast component (Fig. 2). Moreover, in a complementary experiment, we found that addition of exogenous AChE signifi- 
A
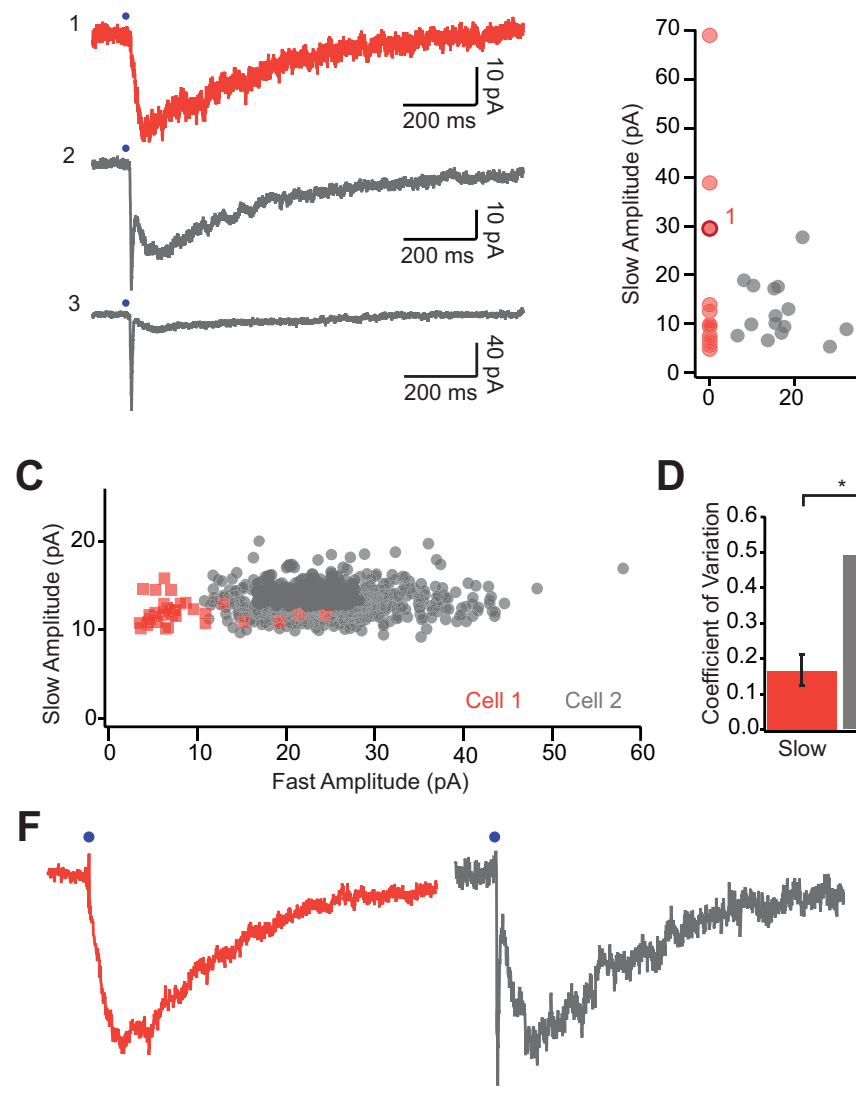

B

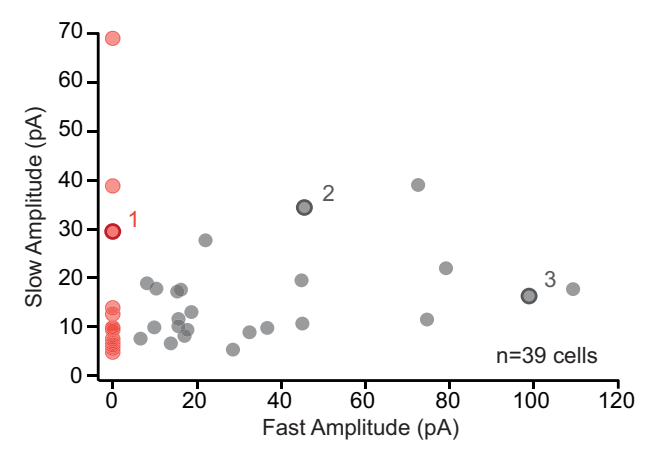

E

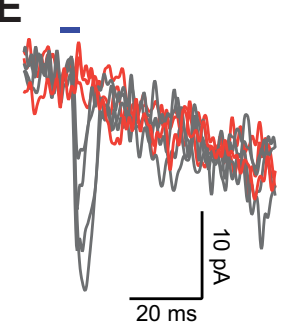

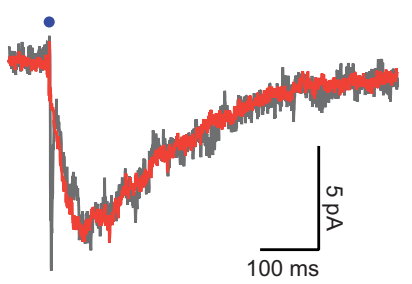

Figure 6. Fast and slow nicotinic EPSCs exhibit different response variability. $\boldsymbol{A}$, Responses of three $L 1$ interneurons labeled $1-3$ in $\boldsymbol{B}$. $\boldsymbol{B}$, Amplitudes of the fast and slow nicotinic EPSCS were plotted for $39 \mathrm{~L} 1$ interneurons. Each symbol represents one cell. Red symbols highlight the cells for which no fast EPSC was detected. $C$, Single-trial amplitudes of the fast and slow nicotinic EPSCs were plotted for two cells. Red symbols represent response amplitudes for the cell displayed in $\boldsymbol{E}$ and $\boldsymbol{F}$. $\boldsymbol{D}$, The coefficient of variation for the fast component $(n=6$ cells) was significantly greater than the coefficient of variation for the slow component ( $n=5$ cells). ${ }^{*} p<0.01$, Wilcoxon rank-sum test. $\boldsymbol{E}$, Expanded time scale of a dual-component nicotinic response for the same cell as in $\boldsymbol{C}$. Seven individual responses are displayed; red traces represent trials in which the fast component failed. The gradual slope in all five traces represents the rise of the slow component. $\boldsymbol{F}$, Dual-component nicotinic response for the same cell as in $\boldsymbol{C}$. Responses containing only a slow component (left) and responses containing both a fast and slow component (middle) were averaged separately and superimposed (right). $\boldsymbol{A}-\boldsymbol{F}$, Blue circles and tick marks represent photostimulation.

cantly attenuated the slow component but had no significant effect on the amplitude or time course of the fast component (Fig. 3). Finally, the fast component exhibited high trial-to-trial response variability and occasional failures. These data suggest that the fast component is mediated by a limited number of release sites operating over a short diffusion pathway, consistent with transmission at a conventional synapse.

The $\alpha 7$ receptors mediating the fast component exhibit exceptionally fast rates of desensitization. Thus, an alternative explanation for our data is that the rapid decay of the fast component reflects fast desensitization of $\alpha 7$ receptors in response to a prolonged transient of ACh. By rapidly applying ACh onto nucleated patches, we determined that a relatively high concentration of $\mathrm{ACh}$ is required to mimic the time course of the fast component (Fig. 4). Thus, we conclude that conventional synaptic transmission, where the concentration of transmitter at the postsynaptic receptor is high, best explains the kinetics of the fast nicotinic EPSC. Notably, perisynaptic $\alpha 7$ receptors, located near release sites but outside the postsynaptic density, have been shown to generate fast nicotinic responses in the chick ciliary ganglion (Coggan et al., 2005; Stanchev and Sargent, 2011). Our data cannot distinguish synaptic from perisynaptic localization of $\alpha 7$ receptors since both depend on short diffusion pathways from single release sites.

\section{Mechanisms underlying the slow component}

In contrast to the fast component, we found that the slow component was highly sensitive to perturbations of AChE (Figs. 2, 3), suggesting that the slow component is mediated by transmitter diffusing over a relatively long distance. Under these conditions, it is expected that many release sites would contribute to the slow response, resulting in low trial-to-trial variability. Indeed, we found that the slow component was much less variable than the fast component. This disparity was not explained by a difference in release probabilities between varicosities mediating the two components, as the fast and slow EPSCs recovered from pairedpulse depression at similar rates (Fig. 5).

Recent anatomical studies indicate that a prominent fraction of cholinergic varicosities do not form synaptic junctions with postsynaptic neurons (Yamasaki et al., 2010; for review, see Lendvai and Vizi, 2008). Together with these anatomical findings, our data suggest that the slow non- $\alpha 7$ response is mediated by nonsynaptic varicosities whereas the fast $\alpha 7$ response is mediated by relatively sparse synaptic contacts with cortical interneurons (Fig. 7).

\section{Comparison with other nicotinic synapses}

There are relatively few studies investigating the synaptic mechanisms underlying endogenous nicotinic signaling in the CNS. 
Here we demonstrate a dual-component nicotinic EPSC comprised of a fast $\alpha 7$ and slow non- $\alpha 7$ receptor-mediated response and provide physiological evidence that these two components reflect synaptic and nonsynaptic transmission, respectively. Interestingly, the kinetics of these cortical responses closely resemble the kinetics of the fast (Alkondon et al., 1998; Frazier et al., 1998) and slow (Bell et al., 2011; English et al., 2012) nicotinic responses reported in the hippocampus and striatum. While these studies did not examine the synaptic mechanisms generating the nicotinic response, their similarity to our data suggests that nicotinic signaling may operate by conserved mechanisms throughout the forebrain.

In the interpeduncular nucleus (IPN), Ren et al. (2011) observed a very slow nicotinic response ( $5 \mathrm{~s}$ decay $\tau$ ) elicited only by tetanic stimulation of cholinergic fibers, suggesting nonsynaptic ACh transmission. Notably, our slow response is tenfold faster than that reported in the IPN and is elicited by single stimulations of cholinergic axons, indicating a significant difference in structure between these two cholinergic synapses. In the spinal cord, heteromeric nicotinic receptors generate a biphasic response whose slow component is selectively modulated by perturbation of AChE, leading the authors to conclude that these receptors are likely activated by spillover of ACh (d'Incamps et al., 2012). Similarly, the slow component of the cortical nicotinic EPSC, which we propose is mediated by nonsynaptic transmission, is selectively modulated by addition or blockade of AChE.

In the spinal cord, d'Incamps et al. (2012) found that a significant portion of the slow nicotinic EPSC remained when the cell was depolarized to $0 \mathrm{mV}$, suggesting that much of the response is transmitted through gap junctions. Indeed, the authors demonstrated that the response at $0 \mathrm{mV}$ was abolished by gap junction blockers. In the cortex, L1 interneurons are known to be interconnected by gap junctions; thus, some fraction of the nicotinic EPSC must be mediated by gap junctions. However, we found that the slow nictonic EPSC was largely diminished at $0 \mathrm{mV}$, suggesting that, in the cortex, gap junctional coupling is unlikely to mediate a large fraction of the slow nicotinic EPSC.

\section{Functional significance}

Recent studies suggest that subcortical neuromodulatory systems may exert temporally precise control over postsynaptic targets. For example, serotonergic fibers from the median raphe nucleus have been shown to evoke rapid EPSCs in hippocampal interneurons (Varga et al., 2009). Similarly, in the interpeduncular nucleus, cholinergic axons from the habenula co-release glutamate and ACh to produce both rapid EPSCs and a slow nicotinic inward current (Ren et al., 2011). Thus, by providing evidence for conventional cholinergic synapses mediating fast $\alpha 7$ receptormediated EPSCs in the cortex, our data further supports an emerging view that ascending subcortical systems operate not only by slow modulation but also by fast excitation. Such rapid modulatory input could serve to synchronize specific postsynap- tic cell types. Additionally, spatially defined synaptic contacts onto the calcium-permeable $\alpha 7$ nicotinic receptor could provide a local plasticity signal for nearby inputs. Indeed, recent studies suggest that activation of $\alpha 7$ nicotinic receptors may have profound consequences for plasticity of glutamatergic and GABAergic inputs in the hippocampus (Wanaverbecq et al., 2007; Gu and Yakel, 2011).

The time course of the ACh transient after release from BF axons is widely debated (Sarter et al., 2009). Here, we show that the decay of the slow EPSC is prolonged by inhibition of AChE. Thus, the waveform of the slow EPSC (duration, $500 \mathrm{~ms}$ ) provides an upper limit for the time course of ACh following photostimulation and release. This time course is relatively fast, indicating that the cholinergic system may exert temporally precise modulation of behavioral responses, as previously proposed (Parikh et al., 2007).

Is there any functional advantage to signaling via volume transmission? Cholinergic neurons represent a small fraction of the total number of cells in the basal forebrain (Henny and Jones, 2008), yet they prominently innervate the entire cortical mantle and exert a profound influence on cortical processing (Mesulam et al., 1983; Rye et al., 1984; Jones and Wonnacott, 2004; Disney et al., 2007; Goard and Dan, 2009). Cholinergic modulation of cortical activity likely involves activation of acetylcholine receptors located at both postsynaptic and presynaptic sites (Gil et al., 1997; Ji et al., 2001; Wanaverbecq et al., 2007; Kruglikov and Rudy, 2008; Lucas-Meunier et al., 2009). Operating by volume transmission in addition to conventional synaptic transmission enables a limited number of cholinergic axons to efficiently interact with a larger number of receptors than would be possible by synaptic transmission alone.

Currently, AChE inhibitors are the only treatment shown to improve cognitive function in patients with Alzheimer's disease (Birks and Harvey, 2003; Courtney et al., 2004; Howard et al., 2012). We found that inhibiting AChE preferentially impacts the non- $\alpha 7$ nicotinic response. Thus, our data suggest that selectively activating non- $\alpha 7$ nicotinic receptors may pro- 
vide an alternative treatment without the unwanted side effects of global AChE downregulation. Moreover, given that $\alpha 7$ nicotinic receptors are unaffected by AChE inhibition, new treatments targeting both $\alpha 7$ and non- $\alpha 7$ receptors may confer additional therapeutic benefits.

\section{References}

Alkondon M, Pereira EF, Albuquerque EX (1998) alpha-bungarotoxin- and methyllycaconitine-sensitive nicotinic receptors mediate fast synaptic transmission in interneurons of rat hippocampal slices. Brain Res 810: 257-263. CrossRef Medline

Arroyo S, Bennett C, Aziz D, Brown SP, Hestrin S (2012) Prolonged disynaptic inhibition in the cortex mediated by slow, non-alpha7 nicotinic excitation of a specific subset of cortical interneurons. J Neurosci 32: 3859-3864. CrossRef Medline

Bell KA, Shim H, Chen CK, McQuiston AR (2011) Nicotinic excitatory postsynaptic potentials in hippocampal CA1 interneurons are predominantly mediated by nicotinic receptors that contain alpha 4 and beta2 subunits. Neuropharmacology 61:1379-1388. CrossRef Medline

Birks J, Harvey RJ (2003) Donepezil for dementia due to Alzheimer's disease. Cochrane Database Syst Rev 2006:CD001190. Medline

Buisson B, Gopalakrishnan M, Arneric SP, Sullivan JP, Bertrand D (1996) Human alpha4beta2 neuronal nicotinic acetylcholine receptor in HEK 293 cells: a patch-clamp study. J Neurosci 16:7880-7891. Medline

Chu Z, Galarreta M, Hestrin S (2003) Synaptic interactions of late-spiking neocortical neurons in layer 1. J Neurosci 23:96-102. Medline

Clements JD (1996) Transmitter timecourse in the synaptic cleft: its role in central synaptic function. Trends Neurosci 19:163-171. CrossRef Medline

Coggan JS, Bartol TM, Esquenazi E, Stiles JR, Lamont S, Martone ME, Berg DK, Ellisman MH, Sejnowski TJ (2005) Evidence for ectopic neurotransmission at a neuronal synapse. Science 309:446-451. CrossRef Medline

Cordero-Erausquin M, Marubio LM, Klink R, Changeux JP (2000) Nicotinic receptor function: new perspectives from knockout mice. Trends Pharmacol Sci 21:211-217. CrossRef Medline

Courtney C, Farrell D, Gray R, Hills R, Lynch L, Sellwood E, Edwards S, Hardyman W, Raftery J, Crome P, Lendon C, Shaw H, Bentham P (2004) Long-term donepezil treatment in 565 patients with Alzheimer's disease (AD2000): randomised double-blind trial. Lancet 363:2105-2115. CrossRef Medline

Dani JA, Bertrand D (2007) Nicotinic acetylcholine receptors and nicotinic cholinergic mechanisms of the central nervous system. Annu Rev Pharmacol Toxicol 47:699-729. CrossRef Medline

Del Castillo J, Katz B (1954) Quantal components of the end-plate potential. J Physiol 124:560-573. Medline

Descarries L, Gisiger V, Steriade M (1997) Diffuse transmission by acetylcholine in the CNS. Prog Neurobiol 53:603-625. CrossRef Medline

d'Incamps BL, Krejci E, Ascher P (2012) Mechanisms shaping the slow nicotinic synaptic current at the motoneuron-renshaw cell synapse. J Neurosci 32:8413-8423. CrossRef Medline

Disney AA, Aoki C, Hawken MJ (2007) Gain modulation by nicotine in macaque v1. Neuron 56:701-713. CrossRef Medline

Eccles JC, Jaeger JC (1958) The relationship between the mode of operation and the dimensions of the junctional regions at synapses and motor endorgans. Proc R Soc Lond B Biol Sci 148:38-56. CrossRef Medline

English DF, Ibanez-Sandoval O, Stark E, Tecuapetla F, Buzsáki G, Deisseroth K, Tepper JM, Koos T (2012) GABAergic circuits mediate the reinforcement-related signals of striatal cholinergic interneurons. Nat Neurosci 15:123-130. Medline

Ford CP, Phillips PE, Williams JT (2009) The time course of dopamine transmission in the ventral tegmental area. J Neurosci 29:13344-13352. CrossRef Medline

Frazier CJ, Buhler AV, Weiner JL, Dunwiddie TV (1998) Synaptic potentials mediated via alpha-bungarotoxin-sensitive nicotinic acetylcholine receptors in rat hippocampal interneurons. J Neurosci 18:8228-8235. Medline

Gil Z, Connors BW, Amitai Y (1997) Differential regulation of neocortical synapses by neuromodulators and activity. Neuron 19:679-686. CrossRef Medline

Goard M, Dan Y (2009) Basal forebrain activation enhances cortical coding of natural scenes. Nat Neurosci 12:1444-1449. CrossRef Medline

Gu Z, Yakel JL (2011) Timing-dependent septal cholinergic induction of dynamic hippocampal synaptic plasticity. Neuron 71:155-165. CrossRef Medline

Henny P, Jones BE (2008) Projections from basal forebrain to prefrontal cortex comprise cholinergic, GABAergic and glutamatergic inputs to pyramidal cells or interneurons. Eur J Neurosci 27:654-670. CrossRef Medline

Hodge AS, Humphrey DR, Rosenberry TL (1992) Ambenonium is a rapidly reversible noncovalent inhibitor of acetylcholinesterase, with one of the highest known affinities. Mol Pharmacol 41:937-942. Medline

Howard R, McShane R, Lindesay J, Ritchie C, Baldwin A, Barber R, Burns A, Dening T, Findlay D, Holmes C, Hughes A, Jacoby R, Jones R, Jones R, McKeith I, Macharouthu A, O’Brien J, Passmore P, Sheehan B, Juszczak E, et al. (2012) Donepezil and memantine for moderate-to-severe Alzheimer's disease. N Engl J Med 366:893-903. CrossRef Medline

Howe WM, Ji J, Parikh V, Williams S, Mocaër E, Trocmé-Thibierge C, Sarter M (2010) Enhancement of attentional performance by selective stimulation of alpha4beta2 $\left(^{*}\right)$ nAChRs: underlying cholinergic mechanisms. Neuropsychopharmacology 35:1391-1401. CrossRef Medline

Ji D, Lape R, Dani JA (2001) Timing and location of nicotinic activity enhances or depresses hippocampal synaptic plasticity. Neuron 31: 131-141. CrossRef Medline

Jones IW, Wonnacott S (2004) Precise localization of alpha7 nicotinic acetylcholine receptors on glutamatergic axon terminals in the rat ventral tegmental area. J Neurosci 24:11244-11252. CrossRef Medline

Kruglikov I, Rudy B (2008) Perisomatic GABA release and thalamocortical integration onto neocortical excitatory cells are regulated by neuromodulators. Neuron 58:911-924. CrossRef Medline

Lendvai B, Vizi ES (2008) Nonsynaptic chemical transmission through nicotinic acetylcholine receptors. Physiol Rev 88:333-349. CrossRef Medline

Letzkus JJ, Wolff SB, Meyer EM, Tovote P, Courtin J, Herry C, Lüthi A (2011) A disinhibitory microcircuit for associative fear learning in the auditory cortex. Nature 480:331-335. CrossRef Medline

Levin ED (2002) Nicotinic receptor subtypes and cognitive function. J Neurobiol 53:633-640. CrossRef Medline

Lucas-Meunier E, Monier C, Amar M, Baux G, Frégnac Y, Fossier P (2009) Involvement of nicotinic and muscarinic receptors in the endogenous cholinergic modulation of the balance between excitation and inhibition in the young rat visual cortex. Cereb Cortex 19:2411-2427. CrossRef Medline

Martin-Ruiz CM, Court JA, Molnar E, Lee M, Gotti C, Mamalaki A, Tsouloufis T, Tzartos S, Ballard C, Perry RH, Perry EK (1999) Alpha4 but not alpha3 and alpha7 nicotinic acetylcholine receptor subunits are lost from the temporal cortex in Alzheimer's disease. J Neurochem 73:1635-1640. Medline

Mesulam MM, Mufson EJ, Wainer BH, Levey AI (1983) Central cholinergic pathways in the rat: an overview based on an alternative nomenclature (Ch1-Ch6). Neuroscience 10:1185-1201. CrossRef Medline

Metherate R, Hsieh CY (2004) Synaptic mechanisms and cholinergic regulation in auditory cortex. Prog Brain Res 145:143-156. CrossRef Medline

Mrzljak L, Levey AI, Goldman-Rakic PS (1993) Association of m1 and m2 muscarinic receptor proteins with asymmetric synapses in the primate cerebral cortex: morphological evidence for cholinergic modulation of excitatory neurotransmission. Proc Natl Acad Sci U S A 90:5194-5198. CrossRef Medline

Parikh V, Kozak R, Martinez V, Sarter M (2007) Prefrontal acetylcholine release controls cue detection on multiple timescales. Neuron 56:141154. CrossRef Medline

Quick MW, Lester RA (2002) Desensitization of neuronal nicotinic receptors. J Neurobiol 53:457-478. CrossRef Medline

Ren J, Qin C, Hu F, Tan J, Qiu L, Zhao S, Feng G, Luo M (2011) Habenula "cholinergic" neurons corelease glutamate and acetylcholine and activate postsynaptic neurons via distinct transmission modes. Neuron 69:445-452. CrossRef Medline

Rossi J, Balthasar N, Olson D, Scott M, Berglund E, Lee CE, Choi MJ, Lauzon D, Lowell BB, Elmquist JK (2011) Melanocortin-4 receptors expressed by cholinergic neurons regulate energy balance and glucose homeostasis. Cell Metab 13:195-204. CrossRef Medline

Rye DB, Wainer BH, Mesulam MM, Mufson EJ, Saper CB (1984) Cortical projections arising from the basal forebrain: a study of cholinergic and noncholinergic components employing combined retrograde tracing and immunohistochemical localization of choline acetyltransferase. Neuroscience 13:627-643. CrossRef Medline 
Sarter M, Parikh V, Howe WM (2009) Phasic acetylcholine release and the volume transmission hypothesis: time to move on. Nat Rev Neurosci 10:383-390. CrossRef Medline

Stanchev D, Sargent PB (2011) alpha7-containing and non-alpha7containing nicotinic receptors respond differently to spillover of acetylcholine. J Neurosci 31:14920-14930. CrossRef Medline

Tamamaki N, Yanagawa Y, Tomioka R, Miyazaki J, Obata K, Kaneko T (2003) Green fluorescent protein expression and colocalization with calretinin, parvalbumin, and somatostatin in the GAD67-GFP knock-in mouse. J Comp Neurol 467:60-79. CrossRef Medline

Turrini P, Casu MA, Wong TP, De Koninck Y, Ribeiro-da-Silva A, Cuello AC (2001) Cholinergic nerve terminals establish classical synapses in the rat cerebral cortex: synaptic pattern and age-related atrophy. Neuroscience 105:277-285. CrossRef Medline

Umbriaco D, Watkins KC, Descarries L, Cozzari C, Hartman BK (1994) Ultrastructural and morphometric features of the acetylcholine innervation in adult rat parietal cortex: an electron microscopic study in serial sections. J Comp Neurol 348:351-373. CrossRef Medline
Varga V, Losonczy A, Zemelman BV, Borhegyi Z, Nyiri G, Domonkos A, Hangya B, Holderith N, Magee JC, Freund TF (2009) Fast synaptic subcortical control of hippocampal circuits. Science 326:449-453. CrossRef Medline

Vizi ES (2000) Role of high-affinity receptors and membrane transporters in nonsynaptic communication and drug action in the central nervous system. Pharmacol Rev 52:63-89. Medline

Wanaverbecq N, Semyanov A, Pavlov I, Walker MC, Kullmann DM (2007) Cholinergic axons modulate GABAergic signaling among hippocampal interneurons via postsynaptic alpha 7 nicotinic receptors. J Neurosci 27:5683-5693. CrossRef Medline

Yamasaki M, Matsui M, Watanabe M (2010) Preferential localization of muscarinic M1 receptor on dendritic shaft and spine of cortical pyramidal cells and its anatomical evidence for volume transmission. J Neurosci 30:4408-4418. CrossRef Medline

Zhang F, Gradinaru V, Adamantidis AR, Durand R, Airan RD, de Lecea L, Deisseroth K (2010) Optogenetic interrogation of neural circuits: technology for probing mammalian brain structures. Nat Protoc 5:439-456. CrossRef Medline 